\title{
Pengaruh Gerakan Literasi Sebagai Budaya Sekolah Terhadap Karakter Peserta Didik Kelas III SDIT Insan Kamil Sidoarjo
}

\author{
Endang Wahju Andjariani ${ }^{1)}$, Kurnia Fuji Astutik ${ }^{2}$ \\ ${ }^{1}$ Program Studi PGSD, STKIP PGRI Sidoarjo \\ ${ }^{2}$ SDIT Insan Kamil Sidoarjo \\ email : endang.wahyu1818@gmail.com ${ }^{1}, \underline{\text { astutikkurnia19@gmail.com }}$
}

\begin{abstract}
Abstrak. Karakter adalah tabiat yang ditumbuhkan kepada seseorang melalui proses pembiasaan atau habituasi. Pembiasaan yang dilakukan terus menerus maka akan menjadi budaya jika karakter sudah membudaya maka tujuan nasional pendidikan akan tercapai. Penelitian ini bertujuan untuk: 1) mendeskripsikan implementasi budaya literasi yang dapat menanamkan nilainilai Pancasila di SDIT Insan Kamil dan 2) menganalisis pengaruh budaya literasi terhadap karakter peserta didik. Metode penelitian menggunakan penelitian korelasional dengan pendekatan kuantitatif. Populasi dalam penelitian ini adalah peserta didik kelas III SDIT Insan Kamil. Teknik pengambilan sampel yang digunakan adalah proportional random sampling. Data dikumpulkan menggunakan kuesioner dan dianalisis menggunakan analisis deskriptif dan regresi linier sederhana. Hasil penelitian ini menyimpulkan bahwa : 1) implementasi budaya literasi di SDIT Insan Kamil sudah sesuai dengan Peraturan Menteri Pendidikan dan Kebudayaan Nomor 23 Tahun 2015 , 2) ada pengaruh yang signifikan budaya literasi terhadap karakter peserta didik. Masih banyak variabel variabel selain budaya literasi yang dapat dieksplorasi untuk lebih menguatkan pendidikan karakter.
\end{abstract}

Kata Kunci: Karakter, Gerakan Literasi, Budaya Sekolah.

\section{PENDAHULUAN}

Pemerintah berupaya untuk memberlakukan Kurikulum 2013 yang bertujuan untuk menjawab tantangan global abad 21. Pendidikan karakter pada Kurikulum 2013 merupakan bahasan yang banyak dibicarakan di kalangan pendidik saat ini selain berita tentang pelecehan seksual anak SD, anarkisme remaja, yaitu tawuran pelajar di sekolah, serta bullying antar pelajar (Islami, Sundari, \& Arifin, 2016).

Salah satu upaya pemerintah adalah menekankan pada pengembangan karakter peserta didik dengan cara menerapkan pembelajaran tematik integratif. Pembelajaran tematik integratif adalah pembelajaran terpadu yang menggunakan tema untuk mengaitkan beberapa mata pelajaran sehingga dapat memberikan pengalaman bermakna pada peserta didik (Trianto, 2011).
Pembelajaran tematik juga dikatakan sebagai pembelajaran yang berusaha untuk mengintegrasikan pengetahuan, keterampilan, nilai, atau sikap pembelajaran, serta pemikiran yang kreatif dengan menggunakan sebuah tema (Suryosubroto, 2009).

Integrasi nilai karakter sangat sesuai untuk usia sekolah dasar (sekitar 6-12 tahun). Usia tersebut merupakan tahap penting bagi pelaksanaan pendidikan karakter. Anak sekolah dasar mengalami perkembangan fisik dan motorik begitu juga perkembangan kepribadian, watak emosional, intelektual, bahasa, budi pekerti, dan moralnya yang bertumbuh pesat. Oleh karena itu jika menghendaki pendidikan karakter dapat berhasil maka pelaksanaannya harus dimulai sejak masa kanak-kanak dan usia SD/MI (Muhsinin, Musyaddad, \& Azim, 2019).

Salah satu faktor yang mempengaruhi rendahnya karakter peserta didik salah satunya adalah faktor budaya organisasi dalam ruang lingkup persekolahan adalah budaya sekolah. Budaya sekolah adalah sekumpulan nilai yang 
melandasi perilaku, tradisi, kebiasaan, kesehariaan, dan simbol-simbol yang dipraktikan oleh kepala sekolah, guru, peserta didik, dan karyawan sekolah (Peterson, D, \& Deal, 1998). Budaya sekolah merupakan ciri khas, karakter atau watak dan citra sekolah tersebut dimasyarakat luas.

Namun, Komarudin Hidayat (2008: 99) berpendapat bahwa, tanpa budaya sekolah yang bagus, akan sulit melakukan pendidikan karakter bagi anak-anak didik. Jika budaya sekolah sudah mapan, siapapun yang masuk dan bergabung di sekolah itu hampir secara otomatis akan mengikuti tradisi yang sudah ada. Jika diperhatikan budaya sekolah diera sekarang mengalami kemunduran yang luar biasa, itu ditandai dengan adanya kecurangan saat ujian nasional, kerjasama dalam mengerjakan soal, tindak plagiasi, membolos, guru sering terlambat dan membolos saat mengajar, sekolah sering dipulangkan lebih awal sampai kebiasaan masa orientasi siswa dengan tindak kekerasan terhadap peserta didik baru. Sebuah sekolah harus mempunyai misi menciptakan budaya sekolah yang menantang dan menyenangkan, adil, kreatif, inovatif, terintegrasi, dan menghasilkan lulusan yang berkarakter dan berkualitas.

Agar kualitas pendidikan meningkat maka budaya literasi harus dikembangkan sesuai dengan hasil dari beberapa penelitian diantaranya: Peran budaya literasi pada peningkatan karakter siswa Sekolah Dasar (Puspita, 2019), Penguatan pendidikan karakter melalui budaya literasi dalam konteks pembelajaran abad 21 di Sekolah Dasar (Harfiyani, 2018), Pengaruh budaya literasi dalam mengembangkan kecerdasan kewarganegaraan (Aini, 2018) dan Peningkatan Kemampuan Menulis Siswa Kelas 3 SD dengan Kegiatan Membaca pada Morning Activities (Amalia \& Andjariani, 2019). Dilatar belakangi oleh teori-teori yang ada serta hasil penelitian terdahulu maka penelitian yang diajukan berjudul: "Pengaruh Gerakan Literasi Sebagai Budaya Sekolah terhadap Karakter Peserta Didik di Kelas III SDIT Insan Kamil Sidoarjo”.

\section{KAJIAN LITERATUR DAN PENGEMBANGAN HIPOTESIS}

\subsection{Pengertian Karakter}

Menurut Lickona dalam (Wibowo, 2013) mengatakan karakter merupakan sifat alami seseorang dalam merespon situasi secara bermoral. Sifat alami itu dimanifestasikan dalam tindakan nyata melalui tingkah laku yang baik, jujur, bertanggung jawab, menghormati orang lain dan karakter mulia lainnya. Pengertian yang dikemukakan Lickona ini, mirip dengan apa yang diungkapkan oleh Aristoteles dalam (Wibowo, 2013) bahwa karakter itu erat kaitannya dengan habit atau kebiasaan yang terus menerus dilakukan. Beberapa ahli mengartikan karakter merupakan gambaran tingkah laku yang menonjolkan nilai benarsalah, baik-buruk, baik secara eksplisit maupun implisit. Begitu pula menurut Samani dan Hariyanto yang mengartikan karakter sebagai cara berpikir dan berperilaku yang khas tiap individu untuk hidup dan bekerja sama, baik dalam lingkup keluarga, masyarakat, bangsa dan Negara (Samani \& Hariyanto, 2013).

2.2.Pengertian Pendidikan Karakter

Lickona dalam (Samani \& Hariyanto, 2013) mendefinisikan pendidikan karakter sebagai upaya yang sungguh-sungguh untuk membantu seseorang memahami, peduli dan bertindak dengan landasan inti nilai-nilai etis. Sementara menurut Ratna Megawangi pendidikan karakter adalah cara untuk mengukir akhlak melalui proses knowing the good, loving the good, and acting the good. Bahwa, suatu proses pendidikan yang melibatkan aspek kognitif, emosi, dan fisik, sehingga akhlak mulia bisa terukir menjadi habit of the mind, heart, and hands (Megawangi, 2010).

Sejalan dengan Rohinah, pendidikan karakter adalah suatu sistem penanaman nilai-nilai karakter kepada warga sekolah yang meliputi komponen pengetahuan, kesadaran atau kemauan, dan tindakan untuk melaksanakan nilai-nilai tersebut. Pendidikan karakter dapat dimaknai sebagai "the deliberate use of all 
Terakreditasi Peringkat 5 (No. SK: 85/M/KPT/2020)

dimensions of school life fosteroptimal character development" (Noor, 2012).

2.3 Penguatan Pendidikan Karakter (PPK)

Penguatan pendidikan karakter bertujuan untuk membangun dan membekali peserta didik yang merupakan generasi emas Indonesia di tahun 2045 dalam menghadapi dinamika perubahan di masa depan, selain itu dengan PPK juga dapat mengembangkan platform pendidikan nasional yang menjadikan pendidikan karakter sebagai jiwa utama dengan memperhatikan keberagaman budaya yang ada di seluruh wilayah Indonesia.

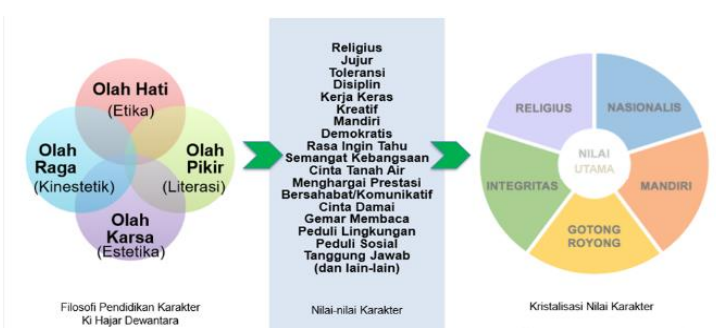

Gambar 1. Pengembangan Nilai-nilai Karakter 2.4 Pengertian Budaya Literasi

Budaya literasi merupakan bentuk pengembangan terhadap asumsi dan kebutuhan perkembangan zaman. Perkembangan zaman di tengah gempuran globalisasi yang merongrong budaya negeri perlu ditindaklanjuti dengan penyiapan dini terhadap generasi penerus negeri. Berbagai bekal diberikan guna mempersiapkan generasi yang mampu berdaya saing dan menjawab tantangan perkembangan zaman ke depan. Literasi sebagai bentuk kemampuan yang diberikan sebagai bekal bagi siswa menjadi jawaban lain terhadap tantangan yang ada saat ini dan masa yang akan datang. Dengan kemampuan membaca situasi dan peluang inilah baginya akan dapat memprediksi sejumlah hal agar tidak salah langkah dan menjadi generasi emas sebagaimana diharapkan (Harfiyani, 2018).

\section{METODE PENELITIAN}

Metode penelitian yang digunakan adalah pendekatan kuantitatif dengan responden penelitian adalah peserta didik serta wawancara kepala sekolah. Jumlah total responden 96 peserta didik yang ditentukan oleh jumlah sampel 10\% dari jumlah total peserta didik kelas III (Arikunto, 2013).

Pengumpulan data dalam penelitian ini menggunakan kuisioner dengan pengukuran Skala Likert yang dapat mengukur persepsi responden. Berdasarkan desain penelitian di atas maka analisis yang digunakan analisis regresi sederhana. Sebelum dilakukan uji analisis regresi sederhana dilakukan uji validitas dan reliabilitas konstruk serta uji persyaratan yaitu normalitas, autokorelasi, multikolinieritas dan linieritas (Wijaya, 2003).

Jika seluruh uji persyaratan sudah memenuhi, maka dilakukan pengujian hipotesis sebagai berikut.

Ho : tidak ada pengaruh budaya literasi terhadap karakter peserta didik

Ha : ada pengaruh budaya literasi terhadap karakter peserta didik

Dengan kriteria uji: terima Ho jika thit $>$ ttab, tolak Ho jika thit < ttab. Selanjutnya untuk menguji apakah korelasi signifikan atau tidak, akan diuji dengan menggunakan uji t dengan melihat signifikansi hitung dengan nilai a $(0,05)$, adapun kriteria pengujiannya sebagai berikut: jika nilai sig.hit $<$ a $(0,05)$ berarti ada pengaruh yang signifikan budaya literasi (X) terhadap karakter peserta didik (Y). Kemudian dilanjutkan dengan menghitung persamaan regresinya yaitu analisis regresi linier sederhana.

Analisis ini untuk mengetahui arah hubungan antara variabel independen dengan variabel dependen apakah variabel independen berhubungan positif atau negatif dan untuk memprediksi nilai dari variabel dependen apabila nilai variabel independen mengalami kenaikan atau penurunan (Sudjana, 2005).

\section{HASIL DAN PEMBAHASAN}

\section{A. Hasil Pelaksanaan}

4.1 Implementasi Budaya Literasi

Program budaya literasi di sekolah meliputi persiapan, pelaksanaan, dan evaluasi berkala dengan rincian sebagai berikut: a) sosialisasi program kepada pimpinan sekolah saat rapat circle 1 (mendapat masukan dari masing-masing koordinator jenjang yang data digunakan untuk menyempurnakan draft 
perencanaan program, b) sosialisasi program kepada pemangku kebijakan di yayasan (Tim Akademik Yayasan). c) membentuk tim literasi yang terdiri atas pimpinan sekolah, guru, tenaga kependidikan dan komite sekolah, d) penyusunan panitia program, e) rapat panitia program, f) sosialisasi program kepada pendidik dan tenaga kependidikan, g) sosialisasi program kepada wali murid, h) rapat koordinasi pelaksanaan workshop dan parenting, i) persiapan tempat untuk workshop dan parenting, j) penyebaran undangan workshop, k) workshop untuk seluruh pendidik dan tenaga kependdikan, 1) parenting untuk wali murid jenjang, $m$ ) evaluasi berkala setiap kelas dan koordinator komite kelas.

Adapun sarana dan prasarana dalam pengembangan program ini adalah: a) buku pelajaran dan non pelajaran yang sesuai dengan usia peserta didik SD kelas III, kertas flip chart dan asturo untuk pohon akhlaq, buku rekam bacaan, rak baca buku, Sedangkan prasarana yang harus dilengkapi adalah: a) ruang perpustakaan yang nyaman untuk belajar, 2) pojok baca di masing-masing kelas dan 3) area baca (UKS, media centre, ruang guru dan ruang kepala sekolah).

Pelaksanaan kegiatan parenting dilakukan di awal tahun pelajaran 20192020. Seluruh wali murid kelas 3 diminta hadir kemudian diberikan ilmu tentang keterampilan membaca lantang bagi orang tua. Kegiatan yang dilaksanakan di aula DPRD Kabupaten Sidoarjo itu dihadiri sekitar 100 wali murid. Lebih dari $70 \%$ diberikan ilmu cara menstimulasi perkembangan berbahasa anak melalui membaca lantang. Peserta parenting dibagi menjadi 10 kelompok. Masing-masing kelompok terdiri atas 9-11 peserta yang didampingi oleh seorang guru. Setiap perwakilan kelompok diberi kesempatan untuk memeragakan keterampilan membaca lantang yang benar. Setelah parenting masing-masing peserta di beri rencana tndak lanjut berupa membaca lantang di depan anaknya dengan judul buku yang direkomendasi sekolah. Setelah 1 semester berjalan penulis berikan angket kepada walimurid terkait hubungan budaya literasi dengan penguatan pendidikan karakter. Angket tersebut menggambarkan persentase ketercapaian penguatan pendidikan karakter dengan interval sebagai berikut:

$$
\begin{array}{lrl}
\text { Amat Baik } & 90<\text { nilai } \leq 100 \\
\text { Baik } & 80<\text { nilai } \leq 90 \\
\text { Cukup } & 70<\text { nilai } \leq 80 \\
\text { Kurang } & \text { nilai } \leq 70
\end{array}
$$

1. Karakter religius

Sila pertama Pancasila mengandung nilai ketuhanan. Didalamnya mengandung makna religius. Karakter religius ini sangat dibutuhkan oleh peserta didik dalam menghadapi perubahan zaman dan degradasi moral, dalam hal ini peserta didik diharapkan mampu memiliki dan berperilaku dengan ukuran baik dan buruk yang di dasarkan pada ketentuan dan ketetapan agama.

Adapun indikator ketercapaian karakter religius di kelas III SDIT Insan Kamil dapat dilihat dari kemampuan sholat 5 waktu meski dingatkan serta mudah menerima nasihat orangtua dibuktikan dengan bersegera melakukan amal kebaikan setelah dinasihati. Berdasarkan hasil angket didapatkan data bahwa kemampuan sholat 5 waktu meski dengan diingatkan amat baik (95\%) dari orang tua dan $91,1 \%$ dari peserta didik dengan nilai rata-rata 93\% dalam kategori amat baik, sehingga dapat disimpulkan karakter religius tercapai .

Indikator dari karakter religius yang kedua adalah mudah menerima nasihat orangtua dibuktikan dengan bersegera melakukan amal kebaikan setelah dinasihati. Berdasarkan hasil angket didapatkan data dengan predikat baik $(87,2 \%)$ dari orang tua dan kurang $(65,1 \%)$ dari peserta didik dengan nilai rata-rata $76 \%$ dalam kategori baik. Hasil rata-rata karakter religius dapat dilihat pada Gambar berikut : 
Terakreditasi Peringkat 5 (No. SK: 85/M/KPT/2020)

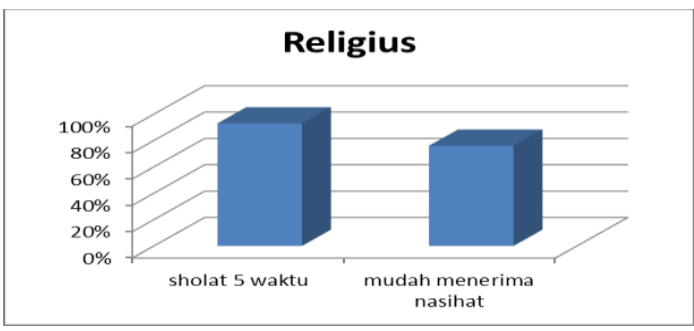

Gambar 2. Diagram Religius

Al Quran secara eksplisit menggunakan nasihat sebagai salah satu cara menyampaikan suatu ajaran. $\mathrm{Al}$ Quran berbicara tentang nasihat, yang dinasihati, objek nasihat, situasi nasihat dan latar belakang nasihat. Teguran atau nasihat cocok untuk mendidik anak karena dengan kalimat-kalimat yang baik dapat mengarahkan hati dan pikiran pada persepsi tertentu. Akan tetapi sebaiknya nasihat dlakukan dengan pendekatan yang baik. Nasihat bisa diberikan dan akan efektif jika sebelumnya ada keteladanan dar orangtua. Sebab keteladanan adalah sarana penting pembentukan karakter.

2. Karakter Nasionalis

Nilai karakter nasionalis merupakan cara berpikir, bersikap, dan berbuat yang menunjukkan kesetiaan, kepedulian, dan penghargaan yang tinggi terhadap bahasa, lingkungan fisik, sosial, budaya, ekonomi,dan politik bangsa, menempatkan kepentingan bangsa dan negara di atas kepentingan diri dan kelompoknya (Samani \& Hariyanto, 2013).

Sub nilai nasionalis antara lain apresiasi budaya bangsa sendiri, menjaga kekayaan budaya bangsa, rela berkorban, unggul, dan berprestasi, cinta tanah air, menjaga lingkungan, taat hukum, disiplin, menghormati keragaman budaya, suku, dan agama. Seluruh sub nilai nasionalis ada dalam nilai-nilai pancasila. Indikator keberhasilan karakter nasionalis di kelas III adalah adalah mampu berkomunikasi menggunakan bahasa Indonesia dengan baik dan benar melalui lisan atau tulisan. Berdasarkan hasil wawancara dengan beberapa wali kelas dapat di paparkan sebagai berikut:
Menurut Ina Nurhasanah "Program budaya literasi dapat menumbuhkan karakter nasionalisme ketika kita mengambil hikmah (nilai nasionalisme) dari suatu kisah yang kita sertai dengan pengamalan dalam kegiatan sehari-hari. Saat ini peserta didik mulai terbiasa mengungkapkan ide dengan bahasa Indonesia baku".

Menurut Chabibah "Program budaya literasi dapat menumbuhkan karakter nasionalisme, karena literasi juga bermakna praktik dan hubungan sosial yang terkait dengan pengetahuan bahasa dan budaya. Peserta didik mulai terbiasa berpendapat dalam bahasa Indonesia sehingga dapat menumbuhkan nasionalisme".

Berdasarkan paparan dua guru di atas dapat disimpulkan bahwa dengan budaya literasi sekolah dapat menguatkan nasionalisme keberbahasaan serta penanaman nilai-nilai Pancasila bagi peserta didik SDIT Insan Kamil kelas III.

3. Karakter Integritas

Nilai karakter integritas merupakan nilai dari Pancasila sila ke-2 yang mendasari perilaku yang didasarkan pada upaya menjadikan dirinya sebagai orang yang selalu dapat dipercaya dalam perkataan, tindakan, dan pekerjaan, memiliki komitmen dan kesetiaan pada nilai-nilai kemanusiaan dan moral (integritas moral). Karakter integritas meliputi sikap tanggung jawab sebagai warga negara, aktif terlibat dalam kehidupan sosial, melalui konsistensi tindakan dan perkataan yang berdasarkan nilai-nilai kebenaran.

Subnilai integritas antara lain kejujuran, cinta pada kebenaran, setia, komitmen moral, anti korupsi, keadilan, tanggung jawab, keteladanan, dan menghargai martabat individu (terutama penyandang disabilitas).

Adapun indikator ketercapaian karakter integritas di kelas III SDIT Insan Kamil dapat dilihat dari kemampuan bersikap jujur dalam lisan dan perbuatan, serta berkomitmen terhadap janjinya. Berdasarkan hasil angket didapatkan data bahwa sikap jujur ananda dari kaca mata orangtua mencapai predikat amat baik $(96,5 \%)$ sedangkan sikap jujur dari kacamata peserta didik mencapai predikat baik $(83,4 \%)$ dengan 
nilai rata-rata $90 \%$ dalam kategori amat baik dan sebanyak $40,6 \%$ dengan predikat kurang lebih memilih berbohong agar tidak dihukum.

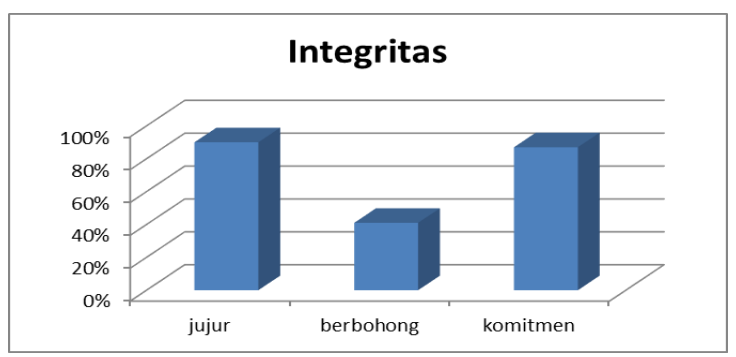

Gambar 3. Diagram Integritas

Dari data diatas menunjukkan bahwa peserta didik kelas III SDIT Insan kamil masih suka berbohong dengan tujuan agar tidak dihukum, karakter tersebut muncul dengan berbagai sebab diantaranya mencari perhatian dan kasih sayang orang tua. Berdasarkan hasil angket didapatkan data bahwa sikap mampu komitmen dengan janjinya kaca mata orangtua mencapai predikat baik $(80,6 \%)$ sedangkan sikap mampu komitmen dengan janjinya dari kacamata peserta didik mencapai predikat amat baik $(94,2 \%)$ dengan nilai rata-rata $87 \%$ dalam kategori baik. Peserta didik kelas III SDIT Insan Kamil sudah mampu berkomitmen terhadap janjinya.

4. Karakter mandiri

Nilai karakter mandiri merupakan sikap dan perilaku tidak bergantung pada orang lain dan mempergunakan segala tenaga, pikiran, waktu untuk merealisasikan harapan, mimpi dan citacita. Subnilai mandiri antara lain etos kerja (kerja keras), tangguh tahan banting, daya juang, profesional, kreatif, keberanian, dan menjadi pembelajar sepanjang hayat (Megawangi, 2010). Berikut ini penulis menyajikan ketercapaian indikator yang ditampilkan dalam diagram :

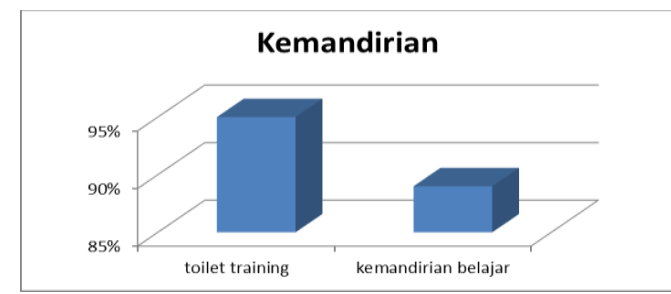

Gambar 4. Diagram Kemandirian

Diagram tersebut mencerminkan tingkat ketercapaian indikator karakter mandiri di kelas III SDIT Insan Kamil, dapat dilihat dari kemampuan bersih diri dan bersuci setelah $\mathrm{BAK} / \mathrm{BAB}$ secara mandiri, serta mampu menyiapkan pelajaran secara mandiri. Berdasarkan hasil angket didapatkan data bahwa sikap kemampuan bersih diri dan bersuci setelah BAK/BAB secara mandiri memperoleh predikat amat baik $(94,2 \%)$ dari kacamata orangtua sedangkan dari kacamata peserta didik mencapai predikat amat baik juga $(96,1 \%)$ dengan nilai rata-rata $95 \%$ dalam kategori amat baik.

Kemampuan menyiapkan pelajaran sendiri memperoleh predikat baik $(88,5 \%)$ dari orangtua .sedangkan dari kacamata peserta didik mencapai predikat juga $(89,5 \%)$ dengan nilai rata-rata $89 \%$ dalam kategori baik. Peserta didik kelas tiga SDIT Insan Kamil sudah mampu menyiapkan buku pelajaran secara mandiri.

5. Karakter gotong royong

Nilai karakter gotong royong mencerminkan tindakan menghargai semangat kerja sama dan bahu membahu menyelesaikan persoalan bersama, menjalin komunikasi dan persahabatan, memberi bantuan/pertolongan pada orang-orang yang membutuhkan. Sub nilai gotong royong yang merupakan nilai-nilai pancasila antara lain menghargai, kerja sama, inklusif, komitmen atas keputusan bersama, musyawarah mufakat, tolong menolong, solidaritas, empati, anti diskriminasi, anti kekerasan, dan sikap kerelawanan.

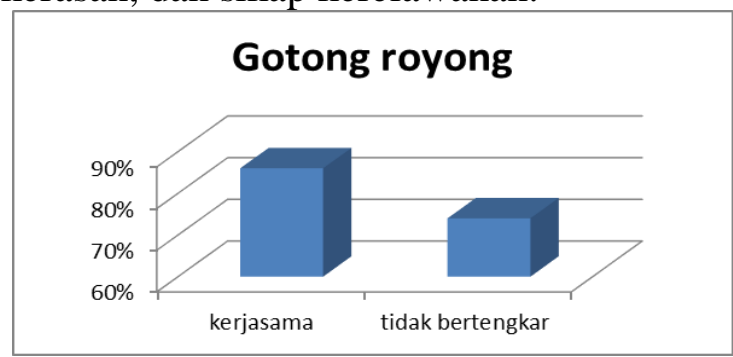

Gambar 5. Diagram Gotong Royong 
Terakreditasi Peringkat 5 (No. SK: 85/M/KPT/2020)

Adapun indikator ketercapaian karakter gotong royong di kelas III SDIT Insan Kamil dapat dilihat dari kemampuan kerjasama dalam anggota keluarga serta tidak bertengkar dengan adik/kakak. Berdasarkan hasil angket didapatkan data bahwa kerjasama dalam anggota keluarga memperoleh predikat amat baik $(86,4 \%)$ dari kacamata orangtua sedangkan dari kacamata peserta didik mencapai predikat amat baik juga $(85,6 \%)$ dengan nilai ratarata $86 \%$ dalam kategori baik.

Indikator ketercapaian karakter gotong royong di kelas III SDIT Insan Kamil dapat dilihat dari mampu kerjasama antar anggota keluarga (tidak bertengkar dengan adik/kakak) didapatkan data dengan predikat amat baik $(92,5 \%)$ dari kacamata orangtua sedangkan dari kacamata peserta didik mencapai predikat kurang $(55,6 \%)$ dengan nilai rata-rata $74 \%$ dalam kategori cukup. Dari data tersebut menunjukkan bahwa peserta didik kelas III masih suka bertengkar dengan adik/kakaknya.

4.2 Pengaruh Budaya Literasi terhadap Karakter Peserta Didik

Berdasarkan keluaran uji validitas dan reliabilitas konstruk pada penelitian ini, perhitungan validitas konstruk dilakukan pada taraf 0,05 untuk variabel karakter peserta didik telah memperoleh 14 item valid dan 3 item lainnya tidak valid. Sedangkan untuk variabel budaya literasi mendapatkan nilai > 0,1671 yang berarti validitas konstruknya signifikan untuk semua item. Sedangkan uji reliabilitas pada taraf 0,05 diperoleh nilai alpha variabel budaya literasi dan karakter peserta didik berturut-turut 0,589 dan $0,612>0,1671$ berarti reliabilitas dari kedua variabel tersebut konsisten. Variabel penelitian tersebut dianalisis menggunakan SPSS 23 untuk Windows.

\section{B. Uji Persyaratan Analisis}

4.3 Uji Normalitas

Berdasarkan keluaran SPSS Uji Kolmogorov-Smirnov, nilai signifikasi untuk data residual variabel budaya literasi dan karakter peserta didik lebih besar dari 0,05 $(0,200>0,05)$ jadi dapat disimpulkan bahwa data berdistribusi normal.

\subsection{Uji Autokorelasi}

Berdasarkan Lampiran 2 didapatkan hasil uji autokorelasi menggunakan Durbin-Watson dengan interval DU < D < 4-DU yaitu 1,6887 < $2,025<2,3113$ yang dapat diartikan bahwa tidak ada autokorelasi sehingga uji hipotesis analisis regresi dapat dilakukan (Ismet, 2019).

4.5. Uji Multikolinieritas

Dari hasil uji multikolinieritas menentukan nilai VIF kurang dari $10(1,000)$ yang didapatkan, menunjukkan bahwa pada data tidak terjadi multikolinieritas, sehingga analisis regresi dapat dilakukan (Ismet, 2019).

4.6 Uji Linieritas

Dasar pengambilan keputusan dalam uji linieritas dapat dilakukan melihat nilai Signifikansi (Sig), diperoleh nilai Deviasi dari Linearity Sig. adalah 0,264 lebih besar dari 0,05. Maka dapat disimpulkan bahwa ada hubungan linear yang signifikan antara variabel budaya literasi dan karakter peserta didik.

4.7 Uji Hipotesis

Berdasarkan keluaran SPSS pada Lampiran 3 mendapatkan persamaan regresi : $\hat{Y}$ $=30,822+0,657 \mathrm{X}, \mathrm{F}$ hitung $>\mathrm{F}$ tabel yaitu $42,835>3,94$ dengan $\rho=0,05$. Sedangkan koefisien determinasinya ( $R$ Square) adalah 0,313 yang berarti ada $31,3 \%$ karakter peserta didik dipengaruhi oleh variabel budaya literasi dan $68,7 \%$ dipengaruhi oleh variabel lainnya yang tidak dikaji dalam penelitian ini.

\section{Pembahasan}

\subsection{Implementasi Budaya Literasi}

Tahapan gerakan literasi di sekolah sebagai upaya membudayakan literasi secara umum dilaksanakan melalui 3 langkah, antara lain: (1) pembiasaan; (2) pengembangan; pembelajaran. Dari ketiganya, dapat dijabarkan, sebagai berikut: (1) Tahap pembiasaan, kegiatan membaca yang menyenangkan di ekosistem sekolah bertujuan menumbuhkan minat terhadap bacaan dan terhadap kegiatan membaca dalam diri warga sekolah; (2) Tahap pengembangan minat baca untuk meningkatkan kemampuan literasi, bertujuan mengembangkan kemampuan memahami bacaan dan 
mengaitkannya dengan pengalaman pribadi, berpikir kritis, dan mengolah kemampuan komunikasi secara kreatif; (3) Tahap pembelajaran berbasis literasi, bertujuan mengembangkan kemampuan memahami teks dan mengaitkannya dengan pengalaman pribadi, berpikir kritis, dan mengolah kemampuan komunikasi secara kreatif dengan menanggapi teks buku yang dibacanya.

Berikut ini hasil telaah yang diperoleh dari hasil observasi, dan wawancara. Di dalam membangun budaya literasi, siswa dibiasakan untuk gemar membaca dan menulis sejak usia dini agar dapat menjadi pembelajar sepanjang hayat. Menurut Direktorat Jenderal Pendidikan Dasar dan Menengah Kementerian Pendidikan dan Kebudayaan menjelaskan bahwa gerakan literasi sekolah adalah suatu usaha yang bersifat partispatif dengan melibatkan seluruh warga sekolah, dan pemangku kepentingan dibawah kordinasi kementrian pendidikan dan kebudayaan.

Sesuai dengan pemaparan di atas, budaya literasi sekolah dilaksanakan dengan membiasakan siswa untuk membaca dan menulis . Seiring dengan pembiasaan yang terus menerus dilakukan, nilai-nilai pendidikan karakter dapat masuk dan menyatu dalam diri siswa sehingga akan menjadi watak atau karakter siswa.

Berdasarkan hasil wawancara dapat dijelaskan bahwa seluruh kelas bawah terutama kelas III sudah melaksanakan budaya literasi diantaranya membaca 15 menit saat morning activity. Hanya saja kegiatan ini tidak dapat dilakukan setiap hari karena terkendala kegiatan senam dan apel yang dilakukan setiap hari Senin dan Rabu. Budaya literasi di SDIT Insan Kamil tidak hanya dilakukan guru tetapi juga peran serta walimurid diantaranya pengadaan buku non pelajaran.

Sesuai dengan pernyataan Rohinah Noor bila dikaitkan dengan perkembangan manusia, proses penguatan karakter hendaknya dilaksanakan secara bertahap sesuai dengan tahap perkembangan siswa. Dengan dilakukan secara bertahap, diharapkan akan mempermudah siswa dalam penerimaan materi akan dapat tercapai secara maksimal sesuai dengan tujuan yang diharapkan (Noor, 2012).

Sebagaimana pemaparan di atas, pelaksanaan penguatan pendidikan nilai-nilai karakter dalam gerakan literasi sekolah dilaksanakan dalam tiga tahap, yaitu

1. Tahap transformasi nilai. Tahap ini merupakan proses yang dilakukan oleh pendidik dalam menginformasikan nilai-nilai yang baik dan kurang baik. Pada tahap ini hanya terjadi komunikasi verbal antara guru dan siswa.

2. Tahap transaksi nilai. Suatu tahap pendidikan nilai dengan jalan melakukan komunikasi dua arah, atau interaksi antara guru dan siswa yang bersifat timbal balik.

3. Tahap transinternalisasi. Tahap ini jauh lebih mendalam daripada tahap transaksi. Pada tahap ini bukan hanya dilakukan dengan komunikasi verbal tapi juga sikap mental dan kepribadian. Jadi, pada tahap ini komunikasi kepribadian yang berperan secara aktif.

Pada tahap transformasi nilai, guru menginformasikan tentang nilai-nilai yang baik dan kurang baik kepada siswa kelas bawah melalui komunikasi verbal sebelum kegiatan literasi mulai dilaksanakan seperti halnya tidak boleh berbicara dengan teman saat guru mulai membaca nyaring dan harus menyimak dengan baik, bila tidak menyimak berarti itu merupakan perbuatan yang tercela. Menceritakan bahwa Nabi Muhammad S.A.W pun ketika sahabatnya berbicara senantiasa mendengar dengan seksama.

Setelah itu, tahap transaksi nilai, terjadi komunikasi dua arah antara guru dan siswa, yakni pada saat guru membaca nyaring, di selasela kegiatan membaca tersebut guru bertanya kepada siswa untuk memancing keaktifan siswa, kemudian siswa menjawab pertanyaan dari guru, bila jawaban yang diberikannya belum tepat, guru kemudian meluruskan jawaban dari siswanya.

Selanjutnya, tahapan transinternalisasi nilai, tahap transinternalisasi nilai pada siswa kelas bawah berada pada fase menyimak, 
Terakreditasi Peringkat 5 (No. SK: 85/M/KPT/2020)

menanggapi, memberi respon yakni memberikan makna baru terhadap nilainilai yang diyakini kebenarannya. Untuk selanjutnya, proses transinternalisasi akan terus dilakukan agar dapat mencapai tahap karakteristik nilai yang konsisten.

Pelaksanaan pembiasaan dalam gerakan literasi sekolah dilaksanakan sesuai dengan pedoman Direktorat Jenderal Pendidikan Dasar dan Menengah Kementerian Pendidikan dan Kebudayaan dalam buku Pedoman Gerakan Literasi Sekolah di Sekolah Dasar, yaitu :

1. Membaca 15 menit sebelum pelajaran dimulai.

2. Menata Sarana dan Lingkungan Kaya Literasi.

3. Menciptakan Lingkungan Kaya Teks.

4. Memilih Buku Bacaan di SD

5. Pelibatan Publik

Pelaksanaan literasi yang dilakukan pada tahap pembiasaan pada siswa kelas bawah di SDIT Insan Kamil telah dilaksanakan sesuai dengan prosedur yang ada, yakni dimulai dari membaca selama 15 menit setelah selesai do'a dan sholat dhuha. Selanjutnya, lingkungan kelas telah ditata sedemikian rupa demi mendukung kegiatan literasi yaitu dibuatkan pojok baca kelas, pohon akhlaq, dan tempelan-tempelan di dinding kelas yang menambah suasana kelas terlihat kaya akan literasi.

Setelah itu lingkungan dibuat kaya akan teks yakni di setiap tempat diberikan tempelan-tempelan yang berisi informasi yang dapat dibaca oleh siswa setiap saat. Kemudian siswa kelas 2 melakukan pembiasaan di kelas dengan buku yang dibawa oleh guru pada saat tersebut, dan jika di perpustakaan siswa bebas memilih buku namun tetap didampingi oleh guru kelasnya.

Tahap terakhir adalah pelibatan publik, di dalam kegiatan literasi yang diadakan di sekolah,buku bacaan masih terhitung sedikit sehingga dalam hal pengadaan buku selain dari guru sendiri, walikelas juga melibatkan orangtua siswa untuk menyumbang buku bacaan, dan juga mengusahakan buku dari penerbit yang bersedia membantu.

Pada tahap pengembangan gerakan literasi sekolah dilaksanakan sebagai berikut

1. Membaca 15 Menit Sebelum Pelajaran Dimulai.

2. Memilih Buku Pengayaan Fiksi dan Nonfiksi.

3. Mendiskusikan Cerita.

4. Membuat Catatan Setelah Membaca.

Pelaksanaan gerakan literasi sekolah di tahap pengembangan ini juga sudah dilakukan sesuai prosedur, kecuali pada tahap buku pengayaan fiksi dan nonfiksi. Kegiatan diawali dengan membaca 15 menit sebelum pelajaran dimulai. Kemudian, karena keterbatasan sumber bacaan yang ada, selain saat di perpustakaan buku yang digunakan masih sebatas pada buku yang dimiliki saja, sehingga belum dapat secara leluasa untuk memilih kategori buku. Selanjutnya siswa juga diminta untuk mendiskusikan cerita, dalam pelaksanaannya menyesuaikan dengan tujuan yang ingin dicapai pada saat kegiatan literasi tersebut. Dan terakhir, membuat catatan setelah membaca, kegiatan ini selalu dilaksanakan siswa kelas bawah bahkan di kelaspun sudah tersedia buku rekam bacaan untuk digunakan oleh siswa membuat catatan, gambar atau tulisan setelah selesai membaca.

Sebagai tindak lanjut dari kegiatan yang dilakukan, perlu diadakan evaluasi yang merupakan sebuah proses pengumpulan data untuk menentukan sejauh mana, dalam hal apa, dan bagian mana tujuan pendidikan sudah tercapai, bagian apa yang belum dan apa penyebabnya. Sesuai dengan pemaparan diatas, evaluasi sangat penting dilakukan dalam setiap kegiatan pembelajaran.

Dengan adanya evaluasi ini, sekolah dapat mengukur sejauh mana keberhasilan program pendidikan dilakukan, serta dapat mengetahui penyebab dari program kegiatan yang dilaksanakan belum dapat berjalan dengan maksimal. Pelakasanaan evaluasi dilakukan dengan memberikan catatan khusus di buku rekam.bacaan siswa yang disesuaikan dengan tujuan menulis pada saat itu, misalnya fokus ada ejaan siswa, atau tanda baca siswa. 
Terakreditasi Peringkat 5 (No. SK: 85/M/KPT/2020)

4.9 Hasil Analisis Regresi Sederhana Pengaruh Budaya Literasi terhadap Karakter Peserta Didik

Hasil penelitian ini membuktikan secara empiris bahwa perolehan koefisien regresi sederhana antara budaya literasi dengan karakter peserta didik sebesar 0,657 dalam kategori positif. Angka ini mengandung artian bahwa setiap penambahan $1 \%$ budaya literasi maka akan meningkatkan karakter peserta didik sebesar 0,657. Hal ini menunjukkan hubungan searah diantara kedua variabel, dimana semakin tinggi budaya literasi sekolah maka akan semakin baik karakter peserta didiknya.

Demikian pula sebaliknya, semakin rendah budaya literasi sekolah maka akan semakin rendah karakter peserta didiknya. Hasil penelitian ini sejalan dengan penelitian yang dilakukan oleh Harfiyani (2018), Aini (2018) dan Puspita (2019) yang menyatakan bahawa budaya literasi sekolah mampu meningkatkan karakter peserta didik sekolah dasar (Harfiyani, 2018), (Aini, 2018) dan (Puspita, 2019).

Berdasarkan keluaran SPSS tersebut diketahui bahwa nilai sig.hit $<\mathrm{a}$ yaitu $0,000<0,05$ berarti H0 di tolak sehingga dapat disimpulkan bahwa ada pengaruh yang sangat signifikan budaya literasi (X) terhadap karakter peserta didik (Y).

\section{KESIMPULAN}

1. Implementasi budaya literasi sekolah di SDIT Insan Kamil dilaksanakan sesuai dengan pedoman Direktorat Jenderal Pendidikan Dasar dan Menengah Kementerian Pendidikan dan Kebudayaan yang berdampak pada penguatan pendidikan karakter.

2. Penguatan pendidikan karakter peserta didik dapat dilaksanakan secara optimal melalui proses habituasi dalam keseharian peserta didik melalui budaya literasi karena berdasarkan keluaran spss diketahui bahwa nilai sig.hit $<\mathrm{a}$ yaitu $0,000<0,05$ berarti H0 ditolak sehingga dapat disimpulkan bahwa ada pengaruh yang sangat signifikan budaya literasi $(\mathrm{X})$ terhadap karakter peserta didik (Y).

\section{SARAN}

1. Kepemimpinan kepala sekolah diharapkan menciptakan program-program habituasi yang dapat menumbuhkan budaya positif di sekolah

2. Cara lain untuk menguatkan pendidikan karakter adalah suri tauladan dari guru secara terus menerus.

3. Menambahkan karakter hidup bersih dan sehat pada penguatan pendidikan karakter agar bisa survive di era pandemic dan menjadi pembiasaan baik pada masa new normal.

\section{DAFTAR PUSTAKA}

Aini, D. N. (2018). Pengaruh Budaya Literasi Dalam Mengembangkan Kecerdasan Kewarganegaraan. Biormatika Jurnal Ilmiah FKIP Universitas Subang, 4(1), 110.

Amalia, R., \& Andjariani, E. W. (2019). Peningkatan Kemampuan Menulis Siswa kelas 3 SD dengan Kegiatan Membaca pada Morning Activities. Jurnal Edukasi, Vol 5. No 2. https://ejournal.stkippgrisidoarjo.ac.id/index.pxp/je/article/view/17

Arikunto, S. (2013). Prosedur Penelitian: Suatu Pendekatan Praktik. Jakarta: Rineka Cipta.

Harfiyani, A. (2018). Penguatan pendidikan karakter melalui budaya literasi dalam konteks pembelajaran abad 21 di Sekolah Dasar. Prosding Seminar Dan Diskusi Nasional Pendidikan Dasar 2018, (25285564), 141-150.

Islami, M. A. T., Sundari, R. S., \& Arifin, Z. (2016). Implementasi Pendidikan Karakter Pada Pembelajaran Tematik di Kelas IV SD Negeri 01 Purworejo Sragi Pekalongan. Jurnal Pendidikan, 149-156.

Ismet, B. (2019). Handout Mata Kuliah Statistika.

Megawangi, R. (2010). Pendidikan Karakter Solusi yang Tepat untuk Membangun Bangsa. Jakarta: IHF (Indonesia Herritage Foundation).

Muhsinin, U., Musyaddad, K., \& Azim, F. (2019). Tematik Integratif. 10(I), 51-68. 
Noor, M. R. (2012). Mengembangkan Karakter Siswa Secara Efektif di Sekolah dan di Rumah. Yogyakarta: Pedagogia.

Peterson, D, K., \& Deal, T. E. (1998). The shaping school culture fieldbook (second edition). San francisco: Jossey Bass.

Puspita, A. M. I. (2019). Peran Budaya Literasi pada Peningkatan Karakter Siswa Sekolah Dasar. PEDAGOGIA: Jurnal Pendidikan,8(1),105. https://doi.org/10.21070/pedagogia.v8 i1.2032

Samani, M., \& Hariyanto. (2013). Konsep dan Model Pendidikan Karakter. Bandung: Remaja Rosdakarya.

Sudjana. (2005). Metoda Statistika. Bandung: TARSITO.

Suryosubroto. (2009). Proses Belajar Mengajar di Sekolah. Jakarta: Rineka Cipta.

Trianto. (2011). Desain Pengembangan Pembelajaran Tematik Bagi Anak Usia Dini TK/RA \& Anak Anak Usia Kelas Awal SD/MI. Jakarta: Kencana Prenada Media Group.

Wibowo,A.(2013). Pendidikan Karakter di Perguruan Tinggi. Yogjakarta: Pustaka Pelajar.

Wijaya.(2003). Statistika Non Parametrik. Bandung: TARSITO. 